\title{
The 'Disabled' as a Subject of Law: Utopian Discourse or Pragmatic Paradigm?
}

\author{
Gaurav Mukherjee*
}

\section{Abstract}

Legal systems across the world have envisaged the 'subjects of law' on the basis of gender, race or disability. The feminist school of thought opines that appropriate interventions are necessary on the identified structures that have the male non disabled as the subject of its legal discourse. The critical legal school believes that legal systems are built in ways that benefit certain groups of persons who seek to perpetuate the status quo. This paper seeks to understand the prevailing law in relation to the access to justice for individuals with disability and answer whether accommodations have been made to comply with India's international obligations vis-à-vis the United Nations Convention on Rights of Persons with Disabilities. It shall also be the endeavour of this paper to compare as to how the developed and developing nations fare with relation to their United Nations Convention on Rights of Persons with Disabilities obligations to ensure that persons with disability have effective access to justice within the boundaries of the legal framework. The paper also demonstrates how the Indian legal system might be altered in order to make better procedural and substantive accommodations by drawing lessons from other nations.

Keywords: Access to Justice, Disability, Legal Framework, Neutral Subject of Law, Procedural Accommodations.

Graduate Fellow, School of Policy \& Governance, Azim Premji University, Bangalore; gaurav.mukherjee@apu.edu.in. 
The arc of history is long, but it curves towards justice.

- Reinhold Niebuhr ${ }^{1}$

\section{Introduction}

While the blindfolded figure of lady justice may be the manifestation of an ideal worth aspiring to, rarely does a situation exist in the real world where the law is seen as treating all individuals equally. The Constitution of India provides that all individuals, irrespective of external determinants, are to be treated equally $^{2}$. While disability does not find a place within the text of the document ${ }^{3}$, the jurisprudence developed by the apex court of India has established principles that prohibit the treatment of unequals equally. The subjects that are governed by law ${ }^{5}$ are never equal, and the supposed neutrality of the law towards external determinants has tended to shift the discourse in a direction that now focuses on dealing with the misconceived notion of neutrality that is prominent in the real world. The United Nations Convention on Human Rights is one of the major human rights instruments that has crystallized the philosophy, that persons with disability have special needs that can only be addressed once the discriminatory treatment that the present legal regime accords to them is recognized. ${ }^{6}$

\footnotetext{
1 Andrei Cherny, The Next Deal: The Future of Public Life in the INFORMATION AGE 208 (2001), in Gary Blasi, Framing Access to Justice: Beyond Perceived Justice for Individuals 42 Loyola L. Rev. 913 (2009).

2 THE CONSTITUTION OF INDIA, Art. 14.

3 The CONSTITUTION OF INDIA, Arts.15, 41. (It may be argued that Part IV of the Constitution of India provides for the recognition of disability through the exhortation on the State to provide for effective provision for securing the right to work, right to education, and right to public assistance in Article 41. Also note that Article 15 of the Constitution of India bars denial of access to certain public institutions on the ground of disability).

4 See, State of West Bengal v. Anwar Ali Sarkar, 1952 S.C.R. 284; Kathi Raning Rawat v. State of Saurashtra, 1952 S.C.R. 435.

5 See, RONALD DWORKIN, LAW's EMPIRE (Harvard University Press, 1986).

6 Peter Bartlett \& Ralph Sandland, Mental Health laW: Policy And PRACTICE 4 (Oxford, 2009).
} 
In India, the Persons with Disabilities (Equal Opportunities, Protection of Rights and Full Participation) Act, 1995 governs the rights of persons with disabilities. It has been drafted as an affirmative action policy, rather than one that emphasizes on anti discrimination and the rights based approach ${ }^{7}$. This fails to recognize the paradigm shift from social welfare to human rights, which supplants the dominant, long held view of disability rights as a form of charity. The social model of disability that now animates most scholarly discussions and policy interventions regards disability not as a medical condition that inheres in the disabled person, but rather as a social condition caused by the interaction between a person's physical or mental traits and social institutions that are structured in a way that makes them inaccessible to people with those traits. ${ }^{8}$

The response to disability, as posited by the scholar Bagenstos, is neither medical treatment nor charity and welfare. ${ }^{9}$ Instead, the proper response is a legislation that prohibits discrimination against people with disabilities and one which accommodates their needs. The legal regime that presently subsists in India has been on vogue since the time of the British Raj, and is in serious need of an overhaul.10 The subject of such a legal system is a healthy male, free from disease or disability. On May 29, 2007, the United Nations Convention on the Rights of Persons with Disabilities (UNCRPD) was opened for signature and India became one of the eighty countries to have signed the document on the first day. Despite possessing the mandate of the union cabinet to ratify the document on the very same day, ${ }^{11}$ India only ratified the UNCRPD on

\footnotetext{
7 JAYNA Kothari, ThE Future of DisAbiLity LAW IN INDIA 175 (Oxford University Press, 2012).

8 Samuel R. Bagenstos, Subordination, Stigma, and Disability, 86 VA. L. REV. 397,426 (2000).

${ }^{9} \mathrm{Id}$. at 427 .

10 See, ERIC STOKES, THE ENGLiSH UTILITARIANS AND INDIA (Oxford University Press, 1989). (This is evident from the fact the most of Indian procedural law was framed in the 1800s and early 1900s, when India was a nation of colonized persons. For an excellent account of colonial laws and the dilemmas of transplantation).

11 Press Information Bureau, Government of India, Signing AND RATIFICATION OF THE UN CONVENTION ON THE RIGHTS FOR PERSONS WITH
} 
October 1, 2007.12 India's ratification is hailed as a significant step forward towards ensuring that rights of persons with disabilities are protected and accommodated in all strata of society. There exist many lacunae in the present legal regime governing persons with disabilities. The primary legislation in this regard, the Persons with Disabilities (Equal Opportunities, Protection of Rights and Full Participation) Act, 1995 (PWD Act, 1995), indicates that India is not yet fully compliant with its treaty obligations. ${ }^{13}$ This article is a culmination of the author's involvement with the process of preparing the First Country Report submitted to the Ministry of Social Justice and Empowerment, New Delhi in pursuance of Article 35 of the UNCRPD.

In the first part of the paper, the author analyzes the views of the critical legal school of jurisprudence, as well as the feminist perspective, on the legal subject as an actor in the legal system. The second part deals with India's commitments under the UNCRPD, and the extant legal regime with specific reference to access to justice of the disabled. The third part presents the experiences from various jurisdictions in respect of specific legislative measures that have been adopted in order to put into operation their respective UNCRPD commitments under Article 13. The author concludes with his views upon the disputed aspect of subject neutrality under Indian law, and puts forth suggestions to remedy the current legal quagmire.

DISABILITIES BY INDIA (29 March 2007) available at http:/ / pib.nic.in/newsite/erelease.aspx?relid=26474_(last visited Oct. 13, 2013).

12 United Nations CONVENTION ON THE Rights OF PERSONS With DISABILITIES - INDIA, RATIFICATION OF U.N.C.R.P.D BY INDIA available at http://uncrpdindia.org/achievements/ratification/_(last visited Oct. 13, 2013).

13 United NATIONS CONVENTION ON THE RIgHTS OF PERSONS With DISABILITY art. 13, 24 January 2007, A/RES/61/106. 


\section{The Subject of Law: Feminist Conception}

Feminist jurists consider that legal systems have been constructed with a male subject in mind. ${ }^{14}$ Considering the troubles of other disadvantaged sections, the feminists posit that, presently, the law is unmindful of other factors such as disability and race. ${ }^{15}$ Such constructs are guilty of essentialism, and assumes that the definitions of experience that the law seeks to accord are male centric.

The fundamental assertion of early schools of feminism, that has undergone considerable evolution in later stages, was the idea that 'sex' was defined as biology and 'gender' was defined as the attributes constructed around biology and they are separable. Consequently, the prevalent view was that a woman is made, not born. ${ }^{16}$ If gender is to be a social construct, the content of which is radically contingent, there exists a potential for its dramatic change. It was under the influence of this emphasis on the social construction of gender that most early feminists and legal scholars concerned with discrimination against women treated women as a homogenous group and recognized that women were differently situated from men. ${ }^{17}$

Feminists advocate that the identification of instances where the subject of law is not neutral to sex or other social determinants like disability, and questioning this in time is an effective challenge to the status quo. The next step is to identify interventions that can alter the status quo, and ensure that the regime is altered in a manner that acknowledges the differences in the way that various subjects experience a legal reality, which would thereby bring a possible change in attitude and consequently, a law that would rectify this conundrum.

14 M.D.A FREEMAN, LLOYD'S INTRODUCTION TO JURISPRUDENCE 1036 (Sweet \& Maxwell 8th ed. 1994).

15 Id at 1037.

16 Angela Harris, Race and Essentialism in Feminist Legal Theory, 42 STAN. L. REV. 583 (1990).

17 Jennifer Nedelsky, The Challenges of Multiplicity, 89 MiCH. L. REV. 1591 (1991). 
The relevance of the above mentioned analysis arises from the author's assertion that the Indian legal system does not accommodate persons with disabilities, and that the overwhelming subject of Indian laws have been those who do not experience the sort of barriers in accessing justice that persons with disabilities do.

\section{Critical Legal Thought}

The critical legal movement, that developed in the 1970s primarily emphasized on the political aspect of law. The proponents of this movement equated law with politics and asserted that law did not have a system of existence outside the ideologies that dominated the society. ${ }^{18}$ About the critical legal thought movement, it has been said, that they are unanimous in their commitment to the creation of a more egalitarian and inclusive society. ${ }^{19}$ They began as a group of law students and junior law professors at American universities, who were disillusioned by the manner in which they were taught the law and the way in which it was applied in practice. ${ }^{20}$ The main argument of the critical legal scholars against the liberal school of legal thought (which defends a system of rights and principles), which claimed to apply law in the form of neutral doctrines independent of their basis in social and political affairs, was in reality only an effort by the law to conceal the injustices of imbalances in the society. ${ }^{21}$ When they refer to politics in this sense, the same indicates the various forms of power i.e. economic, social, political, military or technological power. Thus, the relationship between law and politics as analyzed by the critical legal scholars is essentially a study of how the instrument of law justifies, through its rhetorical use, injustice perpetuated by the

\footnotetext{
18 FREEMAN, supra note 14 at 936 (1994).

${ }^{19} \mathrm{Id}$. at 935.

20 Calvin Woodard, Toward a "Super Liberal State", THE N. Y. TIMES, SUNDAY, Nov. 23, 1986.

21 Roberto Unger, The Critical Legal Studies Movement, 96 HAR. L. REV. 561, 675 (1983). ("When we came, they [the law professors] were like a priesthood that had lost their faith and kept their jobs. They stood in tedious embarrassment before cold altars. But we turned away from those altars and found the mind's opportunity in the heart's revenge.").
} 
various power holders in the society, 22 for example, by justifying injustices against the weaker interests in society in the name of legal reasoning or procedural fairness or the application of the rule of law. 23

The critical legal scholars therefore only have one objective; to demonstrate the way the legal system works at many different levels to shape popular consciousness towards accepting the legitimacy of the status quo, and to outline ways by which lawyers can effectively resist these efforts in building a movement for fundamental social change. ${ }^{24}$ They believe that the law perpetuates injustice principally through its indeterminacy. According to them law is a plastic medium that subtly conditions how we experience social life. ${ }^{25}$ Legal discourses are in a sense a tool for the way we look at the world, and what we consider as reality.26 To define this more simply, J Balkin states that law creates truth itself. By granting labels, categories and descriptions to certain things, it makes those things real, and it has the power to keep such things real since law has the power to constrain the behavior of persons in accordance with it. It has the power to shape people's beliefs and understandings, and to create a version of reality that is not necessarily the only reality. ${ }^{27}$ Balkin illustrates these aspects of the legal creation of truth by saying that when law defines a particular thing to be true, it automatically becomes true in a legal sense irrespective of whether it is true in another sense. ${ }^{28}$ This creation of

${ }^{22}$ Id. at 4; Robert W. Gordon, New Developments in Legal Theory, THE POLITICS OF LAW 962 (David Kairys, ed. Pantheon, 1982).

23 Jack M. Balkin, Critical Legal Theory Today, in Francis J. Mootz, ON PHILOSOPHY IN AMERICAN LAW 6 (Cambridge University Press, 2008).

24 Roberto Unger, Politics, LlOYD's INTRODUCTION TO JURISPRUDENCE 1054 (Sweet \& Maxwell 8th ed. 1994).

25 Robert Gordon, Law and Ideology, LLOYD'S INTRODUCTION TO JURISPRUDENCE 950 (Sweet \& Maxwell 8th ed. 1994).

${ }^{26} I d$.

27 Jack M. Balkin, The Proliferation of Legal Truth, 26 HARV. J. LAW \& PUB. POL'Y 100, 103 (2003).

${ }^{28} \mathrm{Id}$. at 104 (For eg. If the law says that the fetus is not a person, it is not longer a person legally, even though it may continue to be so in the eyes of religion). 
truth in the legal sense is important because of law's ability to control the imagination of people like "cultural software that shapes the way we think about and apprehend the world" and thus colonizes the human mind in its attempt to proliferate its power through the entire world. ${ }^{29}$

The critical legal scholars present before us the powerful tools borne out of their own disappointment which was widely perceived as the growing gulf between law and justice. Persons with disability are to be accommodated in a manner to ensure their meaningful participation in the legal process. Given the current status of Indian procedural law, access to justice for these persons has become a distant reality, and it is clear that the extant regime only perpetuates a reality that may not necessarily be the only one. However, the recalcitrance of such perceptions among the populace has led to a situation where persons with disabilities find themselves groping in the dark when it comes to their roles, whether as a seeker of legal aid, a complainant, or as an accused in the scheme of Indian legal system. The glaring lacunae in the Indian legal processes in this regard shall be discussed in this article.

\section{Access to Justice: Theoretical Underpinnings}

Conklin's model of access to justice permeates virtually every area of legal discourse. According to this model, there does not exist any substantive criterion of justice independent of, and logically prior to the procedure of reaching a decision itself. ${ }^{30}$ Pure proceduralism focuses upon legal method or legal processes, and the procedure determines as to who wins a dispute, or what goals ought to be sought and the means thereunder. Thus, the procedure, not some independent criterion of justice, is what goes to the substantive outcome and produces justice. As a corollary, when there exists systemic discrimination against a section of the society, the

${ }^{29}$ Jack M. Balkin, The Proliferation of Legal Truth, 26 HARV. J. LAW \& PUB. POL'Y 100, 103 (2003).

${ }^{30}$ William E. Conklin, Whither Justice? The Common Problematic of Five Models of 'Access to Justice', 19 WINDSOR Y.B. ACCESS JUST. 297, 300 (2001). 
outcome of any procedure that it involves will necessarily be unjust. This is an extrapolation of the Rawlsian formulation of justice. He states that through justice as fairness, the original position of equality corresponds to the state of nature in the traditional theory of the state of nature, which Rawls himself admits is purely hypothetical, even when it draws upon the works of Kant. Rawls understands the 'subject' of his theory to be at an original or neutral position, unaware of her social lot in life. Further, against the backdrop of this fair basic structure, Rawls turns to the two principles of justice that provide a method for identifying rules that are, "most appropriate for a democratic society that not only professes but wants to take seriously the idea that citizens are free and equal, and tries to realize that idea in its main institutions." 31 This in the ideal world presents the kind of legal institution that would promote outcomes that are necessarily fair due to the astuteness of its procedure. The marked problems are 'utopian' 32 conception of the legal actor as existing independent of the circumstances that have been imposed upon her, by whatever reason or circumstance. This approach ignores that not all persons are equal, and by virtue of many factors such as race, caste, disability, or economic situation, some may be more vulnerable in a legal system. This is what is called 'the vulnerability paradigm'. ${ }^{33}$

Persons with disabilities are more vulnerable than others. This idea of vulnerability may be framed within Fineman's conception of the construct, which operates upon a critique of formal equality. She posits certain premises that, vulnerability is universal and constant; vulnerability is not situated in the body alone, that is, it may be the product of economic, institutional, and other social harm etc. Such a hypothesis comes to a logical conclusion in the idea that the disadvantage that results from vulnerability is best addressed by

31 Elizabeth A. Pendo, Substantially Limited Justice?:The Possibilities and Limits of a New Rawlsian Analysis of Disability-Based Discrimination, 77 ST. JOHN'S L. REV. 225 (2003).

32 See, THOMAS MORE, UtOPIA (1641) (Wherein the island of Utopia presents a situation on an imaginary island wherein there exists a perfect society).

${ }^{33}$ Martha Albertson Fineman, The Vulnerable Subject: Anchoring Equality in the Human Condition, 20 YALE J.L. \& FEMINISM 1, 3 (2008). 
moving past identity based categories, including protected classes. ${ }^{34}$ This can be treated as being akin to the movement beyond the welfare model that has long been the mainstay of disability activists worldwide. ${ }^{35}$

\section{Access to Justice of the Disabled: Evaluation of the Current Structures in the Indian Legal Regime}

Article 13 of the UNCRPD provides the state parties to adopt certain measures in order to ensure access to justice for persons with disability. ${ }^{36}$ The author, in this part, elaborates upon the existent procedural accommodations in the criminal justice system, where most intervention is necessitated, as was noted by the Supreme Court in Veena Sethi v. State of Bihar. ${ }^{37}$ The amendments that are to be made to bring India in line with its UNCRPD obligations have also been provided therein.

\section{Person with Disability as a Complainant}

Section 2(d) of the Code of Criminal Procedure, 1973 (CrPC) defines a 'complaint' as any allegation made orally or in writing to a magistrate, with a view to his taking action under this Code that some person, whether known or unknown, has committed an offence, but does not include a police report. Section 154 of the CrPC deals with information in cognizable cases and states that all information relating to the commission of a cognizable offence, if given orally to an officer in charge of a police station, shall be reduced to writing by him or under his direction, and be read over to the informants and every such information, whether given in writing or reduced to writing as aforesaid, shall be signed by the person giving it, and the substance thereof shall be entered in a book to be kept by such officer in such form as the state government may prescribe in this behalf. This provision, which

\footnotetext{
${ }^{34}$ Martha Albertson Fineman, The Vulnerable Subject: Anchoring Equality in the Human Condition, 20 YALE J.L. \& FEMINISM 1, 5 (2008).

35 Ani B. Satz, Disability, Vulnerability, And The Limits Of Antidiscrimination, 83 WASH. L. REV. Vol. 513, (2008).

36 Supra note 13.

37 Veena Sethi, 1982 (2) S.C.C. 583.
} 
enumerates the First Information Report (FIR) filing procedure, has to be amended in order to include information given through a sign language interpreter or close family members chosen by the complainant in case of hearing and speech impaired persons. Section 200, CrPC, lays down the procedure for the examination of the complainant. It states that a magistrate taking cognizance of an offence on complaint shall examine upon oath the complainant and the witnesses present, if any, and the substance of such examination shall be reduced to writing and shall be signed by the complainant and the witnesses, and also by the magistrate.

\section{Person with Disability as an Alleged Offender}

Section 164 of the CrPC deals with the recording of confessions and statements and enumerates that any metropolitan magistrate or judicial magistrate may, whether or not he has jurisdiction over the case, record any confession or statement made to him in the course of an investigation under that chapter or under any other law for the time being in force, or at any time afterwards, before the commencement of the inquiry or trial. In section $240 \mathrm{CrPC}$ the procedure for the framing of charges is explained, with a provision for the charge being read and explained to the accused, and he being asked whether he pleads guilty of the offence charged or claiming to be tried. The courts are under an obligation to enquire as to how the family of the person with disability communicates with him or her, and then attempt to understand whether the individual can be made to understand the proceedings. ${ }^{38}$ In order to aid such an understanding the courts are under an obligation to provide for appropriate interpretation facilities. ${ }^{39}$ Section 341 of the CrPC states that, a Judicial Magistrate can submit the proceedings after commitment only if the accused, though not insane, cannot be made to understand the proceedings. This is used by the courts to aid the accused person's understanding of the proceedings at hand.

\footnotetext{
38 V. C. Chacko v. T-C. State, A.I.R. 1957 Ker. 7.

39 In Re Sankaralingam, A.I.R. 1957 Mad. 24.
} 


\section{Person with Disability as a Witness}

The admissibility of evidence is dealt with in the provisions of the Indian Evidence Act, 1872 (IEA), and section 118 enumerates that all persons shall be competent to testify unless the court considers that they are prevented from understanding the question put to them, or from giving rational answer to those questions, by tender years, extreme old age, disease, whether of body and mind, or any other cause of the same kind. A 'lunatic' is deemed unable to testify unless the court deems that he understands the questions put to him. Further, section 119 provides that a witness who is unable to speak may give his evidence in any other manner such as by writing or by signs, provided it must be written and the signs be made in the open court, and such evidence so given shall be deemed to be an oral evidence.

\section{Release of a Mentally Disabled/Unsound Person}

The Supreme Court of India in Veena Sethi v. State of Bihar, ${ }^{40}$ observed that mentally ill under trials were languishing in prison for up to 20 years. Sections 328 and 329 of the $\mathrm{CrPC}$ mandate the medical examination of the accused and allows for the release of a mentally unsound individual who has been accused, if the court determines that there is no prima facie case against him. If the court is able to identify a prima facie case against such an accused person, it has to order the postponement of trial, for as long as the clinical psychiatrist opines, is required for the treatment. ${ }^{41}$ The previous position on requiring surety on release has been struck off by virtue of a recent amendment passed by the Parliament, and corresponding changes have been brought about to section 330, $\mathrm{CrPC}$, which has significantly enlarged the discretion of the court in releasing a mentally ill accused on bail due to their incapacity to be tried, or their inability to defend themselves. The court can, under section 335 additionally permit the release of such accused on the security of a friend or relative or order such accused to be kept in safe custody of jail or in a mental hospital.

40 Veena Sethi, 1982 (2) S.C.C. 583.

$41 \mathrm{Id}$. 


\section{Access to Justice under the Labour Law Framework}

A large section of the Indian population is employed in the formal and informal sectors of the economy. Despite the absence of accurate statistics, it is estimated that out of the 70 million persons with disabilities in the country, only about 1,00,000 have succeeded in obtaining employment in industries. ${ }^{42}$ However, statutory enactments safeguard the rights of persons who are engaged in employment within an industry, and who, in the course of their employment, have acquired some form of disability. The Industrial Disputes Act, 1947 mandates a reference by the appropriate state or central government to specially constitute labour courts and tribunals under the legislation, in cases where an industrial dispute is in existence. ${ }^{43}$ Under the Industrial Disputes Act, 1947, workmen have a right to compensation in case of retrenchment and lay offs. In a large number of cases involving workers who have acquired a disability in the course of their duties, the provisions in chapter VIII of the Persons with Disabilities (Equal Opportunities, Protection of Rights and Full Participation) Act, 1995 are devised to ensure that such persons are not dismissed from employment, 44 and in the event of a lay off, adequate compensation is provided.

The Workmen's Compensation Act, 1923 [renamed as the Employees' Compensation Act, 1923 by the Workmen's Compensation (Amendment) Act, 2009] provides that in case a personal injury is caused to a workman by accident arising out of or in the course of his employment, his employer shall be liable to pay compensation. ${ }^{45}$ Such compensation is determined by the workman's wages at the time of debilitation, and is also dependent on additional multipliers that include expected income and extent of injury, and whether disability is total or partial.46 Section 4 of the Workmen's Compensation Act, 1923 provides a manner for

42 World Facts and Statistics on Disabilities and Disability Issues, available at http://www.disabled-world.com/disability/statistics/ (last visited Oct. 2013).

43 Industrial Disputes Act, 1947, §10.

${ }^{44}$ Md Jani Miya v. APSRTC, 2000(5) A.L.D. 166; K.V. Ranga Reddy v. DIG Border Security Force, MANU/GJ/0579/2004.

45 Workmen's Compensation Act, 1923, § 3.

46 Workmen's Compensation Act, 1923, § 4. 
calculating the amount of damages to be paid, and the percentage of total disability suffered is an important criterion in determining the quantum of compensation paid. ${ }^{47}$ The loss of earning capacity on account of a disability resulting out of an injury suffered in the course of employment is a factor employed by courts in coming to a conclusion on the amount of compensation to be fixed.48 There must exist a causal connection between the disease or disability and the occupation, ${ }^{49}$ and in a majority of cases involving disability arising out of employment, the courts have interpreted the provisions of the Workmen's Compensation Act, 192350 liberally and have taken into account the wages of the workman at the time, expected future earnings, and the loss of earning capacity to award compensation to the disabled workman. ${ }^{51}$

\section{Legal Framework Pertaining to Children with Disabilities}

The Juvenile Justice (Care and Protection of Children) Act was enacted in 2000 to adequately confront the issue of children in situations of social maladjustment, delinquency or neglect. However, special attention in terms of the twin track approach ${ }^{52}$ is necessary in order to effectively address the concerns when children with disabilities are involved in cases under this

\footnotetext{
47 Tamil Nadu Cement Company v. N. Jayapalan, (1994) 1 L.L.J. 838 (Mad.)

$48 \mathrm{Id}$.

49 S.N. Mishra, LABOUR \& INDUSTRIAL LAWS 369 (Central Law Publications, 2009).

50 Workmen's Compensation Act, 1923, §§ 4, 5.

${ }^{51}$ National Insurance Co. Ltd. v. Mubasir Ahmed (2007) 1 L.L.J. 1035 (S.C.)

52 United Nations Convention on the Rights of Persons with Disabilities art. 4, 24 January 2007, A/RES/61/106. (The twin track approach is essentially a requirement of Article 4 of the Convention which lays down two distinct obligations as regards domestic laws of a state party. The approach recognizes the fact that a single, isolated law, no matter how comprehensive, is insufficient to put into practice the mandate of the UNCRPD. It further recognizes the fact that in order to realize the aspirations enshrined in the Convention, it is necessary to overhaul a country's legal system as a whole and therefore a law enshrining the rights and entitlements of PWDs cannot be effective if it is independent and isolated from a supporting legal framework in the general law of a country).
} 
legislation. Under the legislation, children who come into conflict with the law may be remanded to special homes by virtue of section 10,53 where their training and development has to be looked into. State governments, apart from maintaining and establishing special homes for the reception of delinquent juveniles, under this provision, have the power to certify other institutions as being fit for such purposes. This provision has been utilized for the institutionalization of the disabled who are dealt with under this Act. Children without disabilities are to be received in special homes, or designated juvenile homes or observation homes.

\section{Physical Barriers Involved in Accessing Governmental Institutions}

Accessibility to institutions of grievance redressal is inextricably linked to the idea of access to justice. There is an existing legal mandate given to the state under the PWD Act, 1995 to prevent discrimination against persons with disability in terms of the built environment. ${ }^{44}$ Currently, there exist certain problems surrounding the entry into courts and police stations, where narrow entrances and the absence of ramps result in persons in wheelchairs being unable to gain entry. Further, parking facilities for vehicles that transport the disabled are not available in most of the grievance redressal institutions. The Supreme Court of India was recently made disable friendly, with the installation of ramps and other such measures. Additionally, the government recognizes that in most of such establishments, toilets are not constructed in a manner so as to accommodate wheelchairs. The government has taken note of the judgment rendered in Disability Rights Group v. Chief Election Commissioner, ${ }^{55}$ where the Supreme Court of India had directed the state governments to provide for wheelchair access to polling stations, and remarked on the importance of accessibility of disabled persons to governmental institutions, such as polling booths. The office of the Chief Commissioner for Persons with Disabilities (CCPD) has since inception, organized 11 workshops

53 United NATIONS CONVENTION ON THE RIGHTS OF PERSONS WITH DiSABILITIES art. 10, 24 January 2007, A/RES/61/106.

54 The Persons with Disabilities (Equal Opportunities, Protection of Rights and Full Participation) Act, 1995, § 46.

55 Disability Rights Group, Writ Petition No 3063 of 2004. 
on 'barrier free environment and access audit' in which 572 persons from states and union territories were trained on access audit. Buildings and public places like government offices, railway stations, stadia, airports, bus stops, hotels, post offices, and places of worship were access audited through access audit teams and were made accessible to the disabled. ${ }^{56}$ It would be pertinent to note that the literature produced in this area, both by the office of the CCPD 57 and by UNNATI, a nongovernmental organization based in Ahmedabad, Gujarat, 58 has been largely ignored by the government.

\section{Legal Aid and Assistance to the Disabled}

A combined reading of Articles 21 and 22 of the Indian Constitution shows that legal representation is an integral part of the right to equality before the law, and is a constituent of fair process that has been recognised in Indian jurisprudence. Other than the constitutional provisions, section 91 of the Mental Health Act, 1987 makes provision for a right to legal representation and legal aid for persons with mental illness in proceedings under the Act. With specific reference to section 43 of the Mental Health Act, 1987 (enumerating the procedure for release from a mental health institution), the Supreme Court of India, in In Re: Death of 25 chained inmates in Asylum fire in Tamil Nadu ${ }^{59}$ with Saarthak Registered Society $v$. Union of India, 60 has directed that two members of the state legal aid boards shall make monthly visits to all the registered

56 Our Achievements, Office of the Chief Commissioner for Persons with Disabilities, Ministry of Social Justice and Empowerment, Government of India, available at http://www.ccdisabilities.nic.in/page.php.

57 See, Offices of the Chief Commissioner for Persons with Disabilities, India Planning a Barrier-Free Environment, available at http://www.ccdisabilities.nic.in/content/en/docs/PlanningBarrierFreeE nvironment.doc (Last visited Oct. 31, 2013).

58 UnNATI AND HANDicAP InTERnATIONAL, DESIGN MANUAL For A BARRIER- FREE BUILT ENVIRONMENT, December 2004, available at http:/ / www.unnati.org/pdfs/manuals/barrier-free-builtenvironment.pdf (Last visited Oct. 31, 2013).

59 In Re: Death, A.I.R 2002 S.C. 979.

60 Saarthak Registered Society, A.I.R. 2002 S.C. 3693. 
mental health institutions so as to ascertain whether any individual requires assistance with respect to his release from such institution.

The National Legal Services Authority (NALSA) through the National Legal Services Authority (Legal Services to the Mentally Ill Persons and Persons with Mental Disabilities) Scheme, 2010, has put into place a mechanism to provide legal aid to persons with psychosocial and intellectual disability. With these guidelines, concepts such as informed consent, equality, and reasonable accommodation has become part of the legal aid schemes. This has been part of the government's larger effort to harmonize policy in line with the UNCRPD, to ensure effective access to justice to persons with disabilities on an equal basis with others. The guidelines make a distinction between mentally ill and mentally retarded persons, enumerating separate concerns which the legal fraternity has to keep in mind when delivering legal aid. It details the situations under the Mental Health Act, 1987 when mentally ill persons might require assistance and vests the legal aid services institutions with the responsibility of rendering legal assistance in such situations. The government notes that the scheme does not enumerate a special procedure for application for legal aid, which it recognizes as being necessary in the light of Regulation/Rule 3 of the National Legal Services Authority (Free and Competent Legal Services) Regulations, 2010, which provides for an application in writing which has to be made in a prescribed form. These regulations are applicable to all, and in order to provide free legal assistance, a committee would review situations on a case-to-case basis to determine whether the applicant deserves free legal aid. Regulation/Rule 5 of the National Legal Services Authority (Free and Competent Legal Services) Regulations, 2010 requires a certificate of entitlement for free legal aid for individuals. Since obtaining the certificate may be difficult for persons with disabilities, proposals to streamline the procedure to obtain the same are being considered. The government is also attempting to ensure that disability certificates are granted within 30 days of application.

Further, NALSA enumerates several specific situations in the National Legal Services Authority (Legal Services to the Mentally Ill Persons and Persons with Mental Disabilities) Scheme, 2010, 
under which legal aid institutions shall come to the aid of mentally retarded persons, such as safeguarding their rights of inheritance, preventing exploitation, protecting their fundamental rights to health care, securing the right to health services etc.

\section{Role of the Office of the Chief Commissioner for Persons with Disabilities}

Other than the courts, the Office of the CCPD established under section 57 of the PWD Act, 1995 has been made responsible for taking steps to safeguard the rights and facilities afforded to the persons with disabilities. Based on the complaints filed before him/her, if the provisions of the PWD Act, any rules, bye-laws, regulations, executive orders or instructions are violated or are not implemented, the chief commissioner may refer the matter to the concerned authorities. The Act also empowers the chief commissioner to issue a suo motu notice in the event of any non compliance.

The commissioner's office has been an accessible and expeditious site of dispute resolution for persons with disabilities. Most proceedings before the chief commissioner relate to matters of employment, promotion or service. Reliefs granted to petitioners before the chief commissioner include directions for reinstatement and guidelines to establishments to ensure that persons with disabilities are not discriminated against. Under the provisions of the PWD Act, 1995,61 state governments are empowered to constitute the office of the State Commissioner for Persons with Disabilities (SCPD). In accordance with the legislation, all proceedings before the commissioner is deemed to be akin to those before a civil court in India. The state commissioners are empowered to look into the deprivation of rights of persons with disabilities and the non implementation of laws that benefit the concerned constituency. ${ }^{62}$ With persistent efforts of the office of the CCPD, all the states and union territories have appointed SCPDs. Fourteen of such commissioners have been appointed on a full time

61 Persons with Disabilities (Equal Opportunities, Protection of Rights and Full Participation) Act, 1995, § 61.

62 Persons with Disabilities (Equal Opportunities, Protection of Rights and Full Participation) Act, 1995, § 62. 
basis. On the advice of the CCPD, twenty four states have declared district collectors as deputy/additional commissioners, disabilities. Twenty five joint mobile courts of CCPD and SCPDs in fifteen states were held since November 2006 where 10,062 grievances of persons with disabilities concerning various departments of state government/district administration/central government organizations were filed and sorted out on the spot.63 In the year 2009-10, the State Commissioner of Madhya Pradesh received 2411 complaints out of which 2191 were disposed of, while Uttar Pradesh, India's most populous state, disposed of 377 cases after having received 371 complaints. Jharkhand displayed the maximum number of cases reported, with 6468 out of 6603 complaints being disposed off. The office of the CCPD received 21,883 complaints, including the complaints received in the mobile courts till February 2010. Out of them, 20,864 have been disposed off and 1,019 were under progress as on February 28, 2010. 64 Suo motu cases initiated by the office of the CCPD have considerably improved compliance with regard to reservation, admissions, appointment, benefits under poverty alleviation schemes, allotment of land/houses against reservation against reserved quota for persons with disabilities, accessibility of public places/transport etc.

The following table provides insight into the efficiency of the office of CCPD to deal with cases:

\begin{tabular}{|l|c|c|c|c|}
\hline S.N & Year & $\begin{array}{c}\text { Cases received } \\
\text { during the year }\end{array}$ & $\begin{array}{c}\text { Cases carried } \\
\text { forward from } \\
\text { previous year }\end{array}$ & $\begin{array}{c}\text { Cases disposed } \\
\text { off during the } \\
\text { year }\end{array}$ \\
\hline 1. & $2007-8$ & 1178 & 452 & 680 \\
\hline 2. & $2008-9$ & 1161 & 950 & 1103 \\
\hline 3. & $2009-10$ & 931 & 1008 & 1070 \\
\hline 4. & $2010-11$ & 993 & 869 & 1238 \\
\hline
\end{tabular}

63 Our Achievements, Office of The Chief Commissioner for Persons with Disabilities, Ministry of Social Justice and Empowerment, Government of India, available

http:/ / www.ccdisabilities.nic.in/page.php?s=reg\&t=def\&p=achievement s (last visited Oct. 31, 2013).

${ }^{64} \mathrm{Id}$. Office of the CCPD. 


\section{Whether Procedural Practices from Other Jurisdictions can Inform the Indian Experience?}

India is a state party to the UNCRPD and a perusal of the documentation from various state parties present us with a wide variety of measures that have been adopted with respect to operationalizing their obligations under Article 13 of the Convention. While some of the initiatives may not be capable of being directly grafted into the Indian scenario, the following are a summary of the measures that India as a state party should take cognizance of, and resources permitting, should transpose into its legal system.

Chile has enacted a law in order to speed up access to justice, and fast track all cases that involved PWDs, through Law No. 20.146 of 9 March 2007.65 Kenya has enacted the Protection of Children from Sexual Offences Act, 2012, which extends protection to persons with disabilities by providing that in cases of sexual offences where the alleged victim is a person with a mental disability, complainant can also include a person who lodges a complaint on behalf of the alleged victim. 66

Another commendable enactment in this regard is the New Zealand Sign Language Act, 2006, which recognizes the New Zealand Sign Language (NZSL) as an official language of New Zealand. The Act confirms the right of persons who are deaf, to use NZSL in legal proceedings, and sets out principles to guide government departments in their recognition of NZSL. New Zealand has also taken a bold step toward extending a great deal of accommodation toward persons with sensory disabilities in terms of their participation in court proceedings. ${ }^{67}$

65 DEPARTMENT OF ECONOMIC AND SOCIAL AFFAIRS, NOTE BY THE SECRETARIAT COMPILATION OF LEGISLATIVE MEASURES UNDERTAKEN IN THE IMPLEMENTATION OF THE CONVENTION ON THE RIGHTS OF PERSONS WITH DisABILITIES: 2011 UPDATE, Fourth session of the Conference of States Parties to the Convention on the Rights of Persons with Disabilities (New York, 7-9 September 2011) available at www.un.org/disabilities/documents/COP/crpd_csp_2011_crp.5.doc.

${ }^{66}$ Id. Secretariat Note.

67 DEPARTMENT OF ECONOMIC AND SOCIAL AFFAIRS, NOTE BY THE SECRETARIAT COMPILATION OF LEGISLATIVE MEASURES UNDERTAKEN IN THE 
The United Kingdom provides a statutorily backed service that allows for greater levels of communication between a disabled person and the police, and allows for video recording in order to help persons with disability with auditory and visual impairments to better participate in the trials. 68 It has also set up a system of Registered Intermediaries who act as communication professionals while interacting between the police and a person with disability as a participant in the criminal justice system. In the United Kingdom administered territory of Northern Ireland, there has been an introduction of a supporter, whose role is to reduce the witness's anxiety and stress when giving evidence. Permitting the prosecutor to ask the witness some 'warm up' questions to help them relax before the commencement of cross examination is also in practice. Further, access to voice recognition software is available for prisoners with dyslexia.

Under the extant prison rules in Spain, non governmental organisations are allowed to act on behalf of persons with disability who are under trial.69 Through the enactment of the Behindertengleichstellungsgesetz (Equality Law for Disabled People - BGG) (\$§ 12,13), a move has been made in favour of non governmental organizations enabling them to act on a kind of 'class action' against disadvantages of disabled people within the scope of this law. Further, there also exists Social Code (\$ 63 SGB IX) which entitles a non governmental organizations to claim a disabled person's right in a court procedure. This, however, is subject to the disabled person having agreed to do the same.

IMPLEMENTATION OF THE CONVENTION ON THE RIGHTS OF PERSONS WITH DisABILITIES: 2011 UPDATE, Fourth session of the Conference of States Parties to the Convention on the Rights of Persons with Disabilities (New York, 7-9 September 2011) available at www.un.org/disabilities/documents/COP/crpd_csp_2011_crp.5.doc.

68 GREAT BRITAIN. OFFICE FOR DISABILITY ISSUES, UK INITIAL REPORT ON THE UN CONVENTION ON THE RIGHTS OF PERSONS WITH DisABILITIES (Office for Disability Issues, May 2011).

69 Secretariat Note, supra note 65. 


\section{Conclusion}

The concept of the liberal subject is informed by the work of Immanuel Kant, who successfully separates the individual from the external world. ${ }^{70}$ On the other hand, Rawl's subject is a normally active and fully co-operating member of society over a complete life, or someone who is perceived as healthy over a lifetime. ${ }^{71}$ It is fairly evident why this conception is inadequate when discussing a section that is clearly disadvantaged. ${ }^{72}$ While Fineman's formulation eschews the liberal subject, who is viewed as a fully functioning adult, she favors a vulnerable subject, who may have social, economic, or biological limitations. This, in the opinion of the author, takes the leap of faith and imagination that had been lacking in feminist and critical legal thought movement, who posited a problem, but did not take the next step in formulating how to construct a theoretical framework that would allow the academic or policymaker to inform his process of making the law. This line of thinking echoes that of Sandland's who points toward certain deficiencies that plague current academic discourse on disability. ${ }^{73}$ The vulnerabilities of the liberal subject are currently addressed by our legal structures only in particular contexts. For example, laws protect certain disadvantaged groups from discrimination. Fineman argues that this context specific approach not only limits the reach of protection for universal vulnerabilities, but it also fails to address existing inequalities embedded within legal and social structures, such as wage disparities and stigma. ${ }^{74}$

In order to understand exactly why structural adjustments have not successfully addressed or appreciated the differences between individuals with or without a disability, the problem arises when

70 IMMANUEL KANT, KANT'S POlitiCAL Writings 66 (Hans Reiss, ed., 1970).

71 JOHN RAWLS, A THEORY OF JUSTICE 18 (1971).

72 John Rawls, Social Unity and Primary Goods, in UTILITARIANISM AND BEYOND 159, 168 (Amartya Sen \& Bernard Williams eds., 1982).

73 Ralph Sandland, et al., Out of the Darkness and Into the Light: Introducing the United Nations Convention on the Rights of Persons with Disabilities, 8(4) HuM. RTS. L. REV. 741 (2008).

${ }^{74}$ Martha Albertson Fineman, The Vulnerable Subject: Anchoring Equality in the Human Condition, 20 YALE J.L. \& FEMINISM 1, 3 (2008). 
we see that equal treatment without accommodations does not consider or address structural inequalities adequately, and people are treated in a like manner under existing laws and practices that entrench inequalities.

A universally acknowledged dilemma in social welfare policy occurs when lawmakers face a tradeoff between targeted and universal interventions. ${ }^{75}$ This raises the question as to whether the need for a neutral legal subject be reconciled with the need to customize it for persons with disability. The answer lies in the perspective that one adopts, and it is the opinion of the author that the Indian legal system has perpetuated the pretence of neutrality for over a hundred years, while systematically ensuring that discrimination and handicaps persist against persons with disability. This is evident from the criminal procedural law in India, the glaring lack of physical access to courts and other public institutions, and its inertia in amending the age old legal frameworks that are in blatant violation of its international commitments. Consequently, the way forward is to acknowledge the existence of this anomaly, and seeking innovative methods, such as incorporating best practices from different jurisdictions, in order to reform the way in which the Indian legal system works. If the arc of Indian history is to lead to justice, much of its systemically entrenched deficiencies need rectification, and only time can tell as to whether this would be possible.

75 NeIL Gilbert, Transformation of the Welfare State: The Silent SurRENDER OF PUblic RESPONSIBILITY 135 (2002); Samuel R. Bagenstos, The Future of Disability Law, 114 YALE L. J. 1, 70 (2004). 